\title{
In Vitro and In Vivo Genotoxicity Analysis of Gold Nanoparticles
}

\author{
Deepak Srisrimal 1,*代, Darsha Kumar Dhurvas Mohandoss ${ }^{1 \mathbb{D}}$, Abhaya Kumar Srisrimal ${ }^{1}$, Rashmi \\ Dhurvas Darshakumar ${ }^{1}$, S. Prabhu ${ }^{2}$, Shonam Tamarakar ${ }^{2}$, Yogeshkumar Murkunde ${ }^{2}$ \\ 1 Dhanvantari Nano Ayushadi Pvt Ltd, Neelakanta Mehta Street, T. Nagar, Chennai - 600017, Tamilnadu, India \\ 2 Centre for Toxicology and Developmental Research, Sri Ramachandra Institute of Higher Education and Research, No. 1, \\ Ramachandra Nagar, Porur, Chennai - 600116, Tamil Nadu, India \\ * Correspondence: deepak@nanolife.in (D.S)
}

Received: 15.05.2021; Revised: 20.07.2021; Accepted: 24.07.2021; Published: 11.09.2021

\begin{abstract}
Gold nanoparticles have been well recognized for biomedical applications, especially cancer therapeutics. As a preliminary step, it is necessary to investigate the genotoxicity of gold nanoparticles under in vitro and in vivo conditions. In vitro, chromosomal aberration study results showed that gold nanoparticles of $5 \mathrm{mg} / \mathrm{ml}$ concentration did not increase the percentage of chromosomal aberration in human peripheral blood lymphocyte cells compared to the negative control. Gold nanoparticles were evaluated erythrocyte micronucleus formation by in vivo micronucleus assay, and results showed no apparent micronucleus formation in mice after $42 \mathrm{~h}$ exposure of gold nanoparticles. Gold nanoparticles of $600 \mathrm{mg} / \mathrm{kg}$ (body weight) were non-clastogenic in swiss albino mice.
\end{abstract}

Keywords: gold nanoparticles; genotoxicity; aberration; micronucleus; lymphocyte.

(C) 2021 by the authors. This article is an open-access article distributed under the terms and conditions of the Creative Commons Attribution (CC BY) license (https://creativecommons.org/licenses/by/4.0/).

\section{Introduction}

With the advancement of nanotechnology, there is a significant improvement seen in biomedicine, engineering, catalysis, agriculture, and environmental applications. Nanomedicine holds great promise to conquer some limitations of drug delivery mechanism such as poor oral bioavailability, non-specific biodistribution, lack of targeting, poor aqueous solubility, and low therapeutic index [1].

Among nanomaterials, gold nanoparticles have gained more attention due to their unique physicochemical properties such as tunable particle size, large surface to volume ratio, monodispersity, biocompatibility, and their applications such as diagnosis and cosmetics, pharmaceuticals, drug delivery, tissue engineering, and therapeutics [2-5]. However, the biomedical application of gold nanoparticles and their composites is largely limited due to their toxicity. In recent times, green nanotechnology has marked its footprint in the field of biomedical science.

Gold nanomaterials offer unique advantages such as lower toxicity, increased drug life cycle, targeted drug delivery, and improved immunogenicity. Apparently, green methods involve plant-based extracts to prepare gold nanoparticles without employing toxic chemicals or solvents. Therefore, the gold nanoparticles prepared using these green methods are believed to possess low toxicity, but it warrants a detailed investigation of toxicity studies beforehand.

Genotoxicity is studied by changes at the genetic level, including DNA damage and mutations, especially structural or chromosomal changes [6-8]. Chromosome aberration assay 
identifies the agents that can cause genotoxicity and alterations in chromosomal structure in cultured mammalian cells and are implicated in various human genetic diseases and cancers [9].

Chromosome fragments have involved the formation of micronuclei due to chromosomal breaks caused by the clastogenic activity of the test substance. Besides, micronuclei are also formed due to the loss of migration of chromosomes during the anaphase stage as a result of the eugenic effects of genotoxic agents [10,11].

Several efforts were put forth to develop efficient, non-toxic carriers that can selectively deliver the drug to the particular site of action without causing adverse effects. This study was done in order to determine the genotoxic potential of gold nanoparticles through in vitro chromosomal aberration and in vivo micronucleus assay.

\section{Materials and Methods}

\subsection{Materials.}

Gold nanoparticles were bio-synthesized as per the procedure reported earlier [13]. The stability of the gold nanoparticles was studied after six months and characterized using UVVisible spectrometry and transmission electron microscopy. RPMI - 1640 medium, Foetal Bovine Serum (FBS), Phytohaemagglutinin (PHA) were purchased from GIBCO, Cyclophosphamide monohydrate and S9 mix were procured from MP Biomedicals, and Mitomycin $\mathrm{C}$ was purchased from Sigma Aldrich. A rat liver S9 mix procured from Krishgen Biosystems, Mumbai, and stored in the deep freezer, set at $-75 \pm 5^{\circ} \mathrm{C}$ was used in the study.

\subsection{Study compliance.}

Studies were conducted according to Schedule 'Y', Requirements DCGI Guidelines, at Centre for Toxicology and Developmental Research (CEFTE), Sri Ramachandra Medical College \& Research Institute (Tamilnadu, India), and also according to OECD Guidelines for Testing of Chemicals OECD 473 for in vitro Mammalian Chromosomal Aberration Test [13] and OECD 474 for in vivo Mammalian Erythrocyte Micronucleus Test [14] and OECD Series on Principles of Good Laboratory Practice and Compliance Monitoring, Number 1, ENV/MC/CHEM(98)17. In July 2016, the revised in vivo MN test guideline (OECD 474) was adopted into the regulatory framework.

\subsection{In vitro chromosomal aberration assay.}

Blood was collected from healthy volunteers and lymphocyte cells isolated from the blood and which was used as a test system for the present study and approved by the Institutional Ethical Review Committee (IEC No: IEC-N1/17/JUN/60/83) of Sri Ramachandra Medical College and Research Centre (Deemed to be University), Chennai. The healthy blood donors were selected within the age group of 18-35 with no smoking and no recent illness record, and ensure that no recent exposures to genotoxic agents (e.g., Alkylating agents, chemicals, etc.). About $1 \mathrm{ml}$ of anti-coagulated human blood was added with $3.95 \mathrm{ml}$ of complete RPMI-1640 culture medium and kept at $37{ }^{\circ} \mathrm{C}$ with $5 \% \mathrm{CO}_{2}$ for $48 \mathrm{~h}$. After a period of incubation, the cultured lymphocyte cells were exposed to $1.25,2.5,5 \mathrm{mg} / \mathrm{ml}$ gold nanoparticles and further incubated at $37^{\circ} \mathrm{C}$ for $24 \mathrm{~h}$ in a $\mathrm{CO}_{2}$ incubator. The cells were exposed with colchicine $(0.1 \mathrm{mg} / \mathrm{ml})$ up to 70 $\mathrm{h}$, and after $72 \mathrm{~h}$, cells were harvested by hypotonic treatment $(0.075 \mathrm{M} \mathrm{KCl}, 30 \mathrm{~min})$ and fixed with Carnoy's fixative (methanol:acetic acid, 3:1). The slides were stained using 5\% Giemsa 
stain for 6-8 min. Then, slides were coded before microscopic analysis, and 300 cell metaphases were scored per experiment. For statistical analysis, chromosomal aberrations such as Chromosome break, Chromosome gap, Chromatid break, Chromatid gap were considered. The results were analyzed with a one-way analysis of variance (ANOVA) test using Sigma plot. Statistical analysis was performed to identify the mean difference between the gold nanoparticles treated and control groups. The results were considered as significant if the P-value was $<0.05$ (OECD, 2016).

\subsection{In vivo micronucleus assay.}

\subsubsection{Dose preparations.}

Required quantity of test material gold nanoparticles was formulated sequentially from low, mid, and high doses. The required amount of gold nanoparticles was weighed in a labeled beaker, transferred to pestle and mortar, and triturated properly. To this, the required quantity of vehicle (0.05\% Sodium Carboxy Methyl Cellulose) was added and triturated again to make up the final volume to the desired dose concentrations. The concentration was transferred to a labeled beaker. The same steps were followed for the formulation of other doses.

\subsubsection{Animals.}

This experiment was conducted with ethical procedures and approved by the Committee for the Purpose of Control and Supervision of Experiments on Animals (CPCSEA Reg No: 1165/PO/RCBI/S/08/CPCSEA) and Institutional Animal Ethics Committee (IEAC/52/SRU/569/2017) of Centre for Toxicology and Developmental Research Sri Ramachandra Institute of Higher Education and Research (Tamilnadu, India). Swiss albino mice were obtained from in vivo Biosciences (Bengaluru, India) at approximately 6-8 weeks of age. Following, a five to seven-day acclimation period under laboratory conditions and animals were divided into control and treatment groups (six animals in each group). Experimental animals were housed in groups in polypropylene cages. Dedusted and autoclaved paddy husk was used as bedding material. The animals were maintained at room temperature of $20-22{ }^{\circ} \mathrm{C}$ with the relative humidity of 55-61\% and $12 \mathrm{~h}$ light/ 12-h dark conditions. Animals were provided with laboratory rodent pelleted feed procured from approved vendor 'ad libitum'.

\subsubsection{Oral gavage administration study.}

In this study, female rats were divided into 10 groups, five groups for $24 \mathrm{~h}$ and another five groups for $48 \mathrm{~h}$ observations, and each group contained 6 animals. These animals were administered at doses of 0 (control G1-G6), 150 (G3-G8), 300 (G4-G9), 600 (G5-G10) mg/kg b.w (bodyweight), of gold nanoparticles via oral gavage at $24 \mathrm{~h}$ and $48 \mathrm{~h}$. Bone marrow samples were collected from treated animals in each dose group, euthanized after $24 \mathrm{~h}$ and $48 \mathrm{~h}$. Positive control animals (G2-G7) were gavage with $40 \mathrm{mg} / \mathrm{kg}$ b.w of cyclophosphamide at $24 \mathrm{~h}$ and 48 $\mathrm{h}$, and bone marrow samples were collected after the final dose.

\subsubsection{Analysis of bone marrow samples.}

The experimental group of gold nanoparticles treated and positive control rats were sacrificed by cervical dislocation. In order to collect, bone marrow was instilled from the femur, and it was separated from serum using centrifugation. Further, the collected bone marrow cells 
were put on a glass slide and gently smeared using cover glass. Two bone marrow smears were prepared for each animal, and the air-dried slide was fixed using methanol for $5 \mathrm{~min}$. In addition, $8 \%$ of Giemsa solution was used for staining the smear in a glass slide at room temperature for $30 \mathrm{~min}$. Bone marrow smear slide evaluation under light microscopy at 100x magnification. 500 erythrocytes per animal were counted to determine the PCE: NCE ratio. 4000 PCEs per animal was scored to determine the incidence of MNPCEs. Cells with micronucleus were scored as positive for micronuclei, and the number of micronuclei per PCEs was recorded. The ratio of PCE: NCE and the percentage of micro-nucleated polychromatic erythrocytes (MNPCE) were calculated.

\subsection{Statistical analysis.}

Data were expressed in Mean \pm SD. Appropriate statistical analyses were performed to identify the mean difference between the control and test item-treated groups. P-value $<0.05$ was fixed as a significance criterion. Statistical analysis was performed using Sigma plot.

\section{Results and Discussion}

The gold nanoparticles are currently used in various medical fields, such as antibacterial activity, anti-inflammatory, high drug loading capacity, diagnostics [15], and targeting intracellular drug delivery vehicles [16]. In order to find out the genotoxicity of gold nanoparticles, based on that, we carried out a chromosomal aberration assay.

\subsection{UV-Vis and High resolution transmission electron microscope (HR-TEM).}

UV-vis spectra confirm that the formation and stability of the gold nanoparticles and characteristic surface plasmon resonance band occurred at 535nm (Figure 1a). The TEM images confirm the formation of gold nanoparticles. The nanoparticles are polydispersed consisting of triangular, tetragonal, pentagonal, hexagonal, rod, spherical, and with irregular shape [17], the average size of gold nanoparticles ranging from 13 to $62 \mathrm{~nm}$ (Figure 1b).
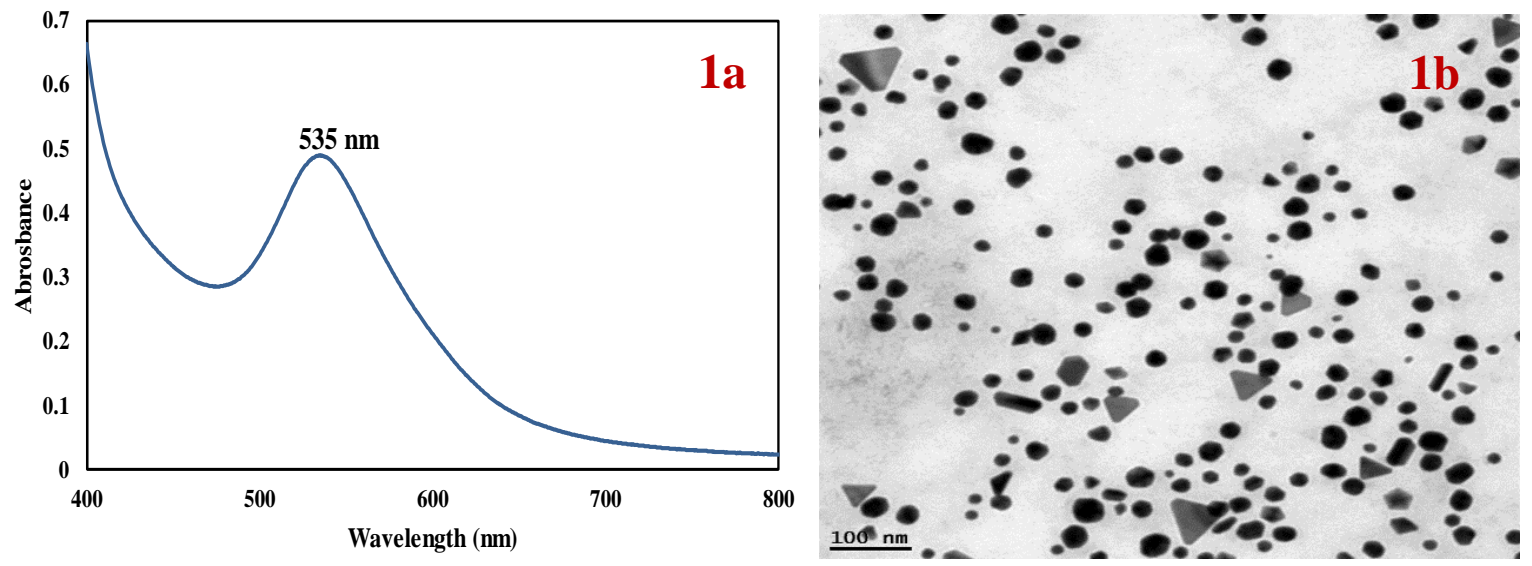

Figure 1. (a) UV-visible spectra of gold nanoparticles. (1b) TEM image of gold nanoparticles.

\subsection{In vitro chromosomal aberration assay.}

The chromosomal aberration study was carried out using human peripheral blood lymphocyte cells treated with different concentrations of 1.25 .2 .5 and $5 \mathrm{mg} / \mathrm{ml}$ of gold nanoparticles for $3 \mathrm{hrs}$ (Short time) without metabolic activation (S9). The results showed that chromosomal aberration was found in gold nanoparticles treated cells and was statistically insignificant compared to the negative control. The positive control (Mitomycin C-11.67\%) 
exhibited a significantly high number of aberrations compared with gold nanoparticles (Table 1). In a long-term study, the cells were treated with metabolic activation $S 9$ and gold nanoparticles. The chromosomal aberration was observed in gold nanoparticles treated cells and was not significant when compared with negative control. The percentage of aberration of positive control (14\%) was significantly higher than the negative control (Table 2). The chromosomal aberration of gold nanoparticles was studied for $24 \mathrm{hrs}$ (long term) with metabolic activation. The results demonstrated that gold nanoparticles do not induce chromosomal aberration in treated cells, whereas positive control showed a high percentage (12\%) of chromosomal aberration (Table 3).

Ring aberration noticed in the test and negative control chromosomes was comparable, and there was no significant difference between them. Positive control results were consistent with the effectiveness of the S9 mix and thus confirmed the sensitivity and validity of the assay. Overall, there is an increase in the percentage of chromosomal aberration in the positive controls of both short and long-term treatments (with and without metabolic activation). More evidently, no statistically significant difference in the chromosomal aberration frequency was observed between the negative controls and all three gold nanoparticle concentrations $(5,2.5$, and $1.25 \mathrm{mg} / \mathrm{ml}$ ). These results were well in agreement with the recent report [18]. No significant difference in the structural chromosomal aberrations was observed in the cells treated with $\mathrm{Au}$ NPs and normal saline control in the presence or absence of metabolic activation. Similarly, Das et al. [19] described the lack of genotoxicity of photosynthesized Au NPs on normal human lymphocytes. Phytosynthesized Au NPs at $6-15 \mu \mathrm{g} / \mathrm{mL}$ were found to be non-genotoxic in HaCaT cells using a comet assay [20].

Table 1. Results of the chromosomal test on gold nanoparticles short term treatment without S9.

\begin{tabular}{|c|c|c|c|c|c|c|c|c|c|c|}
\hline \multirow{3}{*}{ Treatment } & \multicolumn{6}{|c|}{ Total No. of aberration } & \multirow{3}{*}{$\begin{array}{l}\text { Total No. of } \\
\text { aberrations } \\
\text { per culture } \\
\text { without } \\
\text { gaps }\end{array}$} & \multirow{3}{*}{$\begin{array}{c}\text { Aberration } \\
\text { without gaps } \\
(\text { Mean } \pm \text { SD) }\end{array}$} & \multirow{3}{*}{$\begin{array}{c}\text { Aberration } \\
\text { frequency } \\
\text { without } \\
\text { gaps }\end{array}$} & \multirow{3}{*}{$\begin{array}{c}\% \text { of cells with } \\
\text { aberrations } \\
(\text { Mean } \pm \text { SD) }\end{array}$} \\
\hline & \multirow{2}{*}{ Gaps } & \multicolumn{2}{|c|}{$\begin{array}{c}\text { Chromatid } \\
\text { type }\end{array}$} & \multicolumn{2}{|c|}{$\begin{array}{c}\text { Chromosome } \\
\text { type }\end{array}$} & \multirow{2}{*}{\begin{tabular}{|c|} 
Others \\
(ring \\
structure)
\end{tabular}} & & & & \\
\hline & & CTB & CTE & CSB & CSE & & & & & \\
\hline $\begin{array}{l}\text { 5\%DMSO } \\
\text { (Dimethyl sulfoxide) }\end{array}$ & 2 & 0 & 0 & 0 & 1 & 0 & 1 & $0.050 \pm 0.100$ & 0.003 & $0.333 \pm 0.667$ \\
\hline $\begin{array}{l}\text { Mitomycin C } 0.5 \mu \mathrm{g} / \mathrm{ml} \\
\text { (Positive control) }\end{array}$ & 8 & 10 & 4 & 8 & 8 & 5 & 35 & $1.750 * \pm 0.191$ & 0.117 & $11.667 \pm 1.277$ \\
\hline $\begin{array}{l}\text { Gold nanoparticles } \\
5 \mathrm{mg} / \mathrm{ml}\end{array}$ & 4 & 3 & 0 & 1 & 0 & 1 & 4 & $0.200 \pm 0.000$ & 0.013 & $1.333 \pm 0.000$ \\
\hline $\begin{array}{l}\text { Gold nanoparticles } \\
2.5 \mathrm{mg} / \mathrm{ml}\end{array}$ & 1 & 1 & 0 & 1 & 0 & 0 & 2 & $0.100 \pm 0.115$ & 0.007 & $0.667 \pm 0.770$ \\
\hline $\begin{array}{l}\text { Gold nanoparticles } \\
1.25 \mathrm{mg} / \mathrm{ml}\end{array}$ & 1 & 0 & 1 & 0 & 0 & 0 & 1 & $0.050 \pm 0.100$ & 0.003 & $0.333 \pm 0.667$ \\
\hline
\end{tabular}

SD- Standard Deviation; *Significant criteria are fixed as $\mathrm{P} \leq 0.005$

Table 2. Results of the chromosomal test on gold nanoparticles short-term treatment with S9.

\begin{tabular}{|c|c|c|c|c|c|c|c|c|c|c|}
\hline \multirow{3}{*}{ Treatment } & \multicolumn{6}{|c|}{ Total No. of aberration } & \multirow{3}{*}{$\begin{array}{l}\text { Total No. of } \\
\text { aberrations } \\
\text { per culture } \\
\text { without } \\
\text { gaps }\end{array}$} & \multirow{3}{*}{$\begin{array}{c}\text { Aberration } \\
\text { without gaps } \\
(\text { Mean } \pm \text { SD })\end{array}$} & \multirow{3}{*}{$\begin{array}{c}\text { Aberration } \\
\text { frequency } \\
\text { without } \\
\text { gaps }\end{array}$} & \multirow{3}{*}{$\begin{array}{c}\% \text { of cells with } \\
\text { aberrations } \\
(\text { Mean } \pm \text { SD) }\end{array}$} \\
\hline & \multirow{2}{*}{ Gaps } & \multicolumn{2}{|c|}{ Chromatid type } & \multicolumn{2}{|c|}{$\begin{array}{c}\text { Chromosome } \\
\text { type }\end{array}$} & \multirow{2}{*}{$\begin{array}{c}\text { Others } \\
\text { (ring } \\
\text { structure) }\end{array}$} & & & & \\
\hline & & CTB & CTE & CSB & CSE & & & & & \\
\hline $\begin{array}{l}\text { 5\%DMSO } \\
\text { (Dimethyl sulfoxide) }\end{array}$ & 0 & 0 & 0 & 1 & 0 & 0 & 1 & $0.050 \pm 0.100$ & 0.003 & $0.333 \pm 0.667$ \\
\hline $\begin{array}{l}\text { Mitomycin C } \\
0.5 \mu \mathrm{g} / \mathrm{ml} \\
\text { (Positive control) }\end{array}$ & 8 & 13 & 6 & 12 & 7 & 4 & 42 & $2.100 * \pm 0.115$ & 0.140 & $14.000 \pm 0.77$ \\
\hline
\end{tabular}




\begin{tabular}{|c|c|c|c|c|c|c|c|c|c|c|}
\hline \multirow{3}{*}{ Treatment } & \multicolumn{6}{|c|}{ Total No. of aberration } & \multirow{3}{*}{$\begin{array}{l}\text { Total No. of } \\
\text { aberrations } \\
\text { per culture } \\
\text { without } \\
\text { gaps }\end{array}$} & \multirow{3}{*}{$\begin{array}{c}\text { Aberration } \\
\text { without gaps } \\
(\text { Mean } \pm \text { SD })\end{array}$} & \multirow{3}{*}{$\begin{array}{c}\text { Aberration } \\
\text { frequency } \\
\text { without } \\
\text { gaps }\end{array}$} & \multirow{3}{*}{$\begin{array}{c}\% \text { of cells with } \\
\text { aberrations } \\
(\text { Mean } \pm \text { SD) }\end{array}$} \\
\hline & \multirow{2}{*}{ Gaps } & \multicolumn{2}{|c|}{ Chromatid type } & \multicolumn{2}{|c|}{$\begin{array}{c}\text { Chromosome } \\
\text { type }\end{array}$} & \multirow{2}{*}{\begin{tabular}{|c|} 
Others \\
(ring \\
structure)
\end{tabular}} & & & & \\
\hline & & CTB & CTE & CSB & CSE & & & & & \\
\hline $\begin{array}{l}\text { Gold nanoparticles } \\
5 \mathrm{mg} / \mathrm{ml}\end{array}$ & 3 & 2 & 0 & 1 & 0 & 1 & 4 & $0.200 \pm 0.283$ & 0.013 & $1.333 \pm 1.886$ \\
\hline $\begin{array}{l}\text { Gold nanoparticles } \\
2.5 \mathrm{mg} / \mathrm{ml}\end{array}$ & 1 & 0 & 0 & 3 & 0 & 0 & 3 & $0.150 \pm 0.100$ & 0.010 & $1.000 \pm 0.667$ \\
\hline $\begin{array}{l}\text { Gold nanoparticles } \\
1.25 \mathrm{mg} / \mathrm{ml}\end{array}$ & 3 & 0 & 0 & 0 & 1 & 0 & 1 & $0.050 \pm 0.100$ & 0.003 & $0.333 \pm 0.667$ \\
\hline
\end{tabular}

SD- Standard Deviation; *Significant criteria are fixed as $\mathrm{P} \leq 0.005$

Table 3. Results of the chromosomal test on gold nanoparticles long-term treatment without S9.

\begin{tabular}{|c|c|c|c|c|c|c|c|c|c|c|}
\hline \multirow{3}{*}{ Treatment } & \multicolumn{6}{|c|}{ Total No. of aberration } & \multirow{3}{*}{$\begin{array}{c}\text { Total No. } \\
\text { of } \\
\text { aberratio } \\
\text { ns per } \\
\text { culture }\end{array}$} & \multirow{3}{*}{$\begin{array}{c}\text { Aberration } \\
\text { without gaps } \\
(\text { Mean } \pm \text { SD) }\end{array}$} & \multirow{3}{*}{$\begin{array}{c}\text { Aberration } \\
\text { frequency } \\
\text { without } \\
\text { gaps }\end{array}$} & \multirow{3}{*}{$\begin{array}{c}\% \text { of cells wit } \\
\text { aberrations } \\
(\text { Mean } \pm \text { SD) }\end{array}$} \\
\hline & \multirow{2}{*}{ Gaps } & \multicolumn{2}{|c|}{ Chromatid type } & \multicolumn{2}{|c|}{$\begin{array}{c}\text { Chromosome } \\
\text { type }\end{array}$} & \multirow{2}{*}{$\begin{array}{c}\text { Others } \\
\text { (ring } \\
\text { structure) }\end{array}$} & & & & \\
\hline & & CTB & CTE & CSB & CSE & & & & & \\
\hline $\begin{array}{l}\text { 5\%DMSO } \\
\text { (Dimethyl sulfoxide) }\end{array}$ & 2 & 1 & 0 & 0 & 1 & 0 & 2 & $0.100 \pm 0.115$ & 0.005 & $0.667 \pm 0.77$ \\
\hline $\begin{array}{l}\text { Mitomycin C } \\
0.5 \mu \mathrm{g} / \mathrm{ml} \\
(\text { Positive control) }\end{array}$ & 6 & 10 & 6 & 8 & 9 & 3 & 36 & $1.800 * \pm 0.163$ & 0.090 & $1.200 \pm 1.089$ \\
\hline $\begin{array}{l}\text { Gold nanoparticles } \\
5 \mathrm{mg} / \mathrm{ml}\end{array}$ & 2 & 0 & 1 & 1 & 0 & 1 & 3 & $0.150 \pm 0.100$ & 0.009 & $1.000 \pm 0.667$ \\
\hline $\begin{array}{l}\text { Gold nanoparticles } \\
2.5 \mathrm{mg} / \mathrm{ml}\end{array}$ & 2 & 1 & 0 & 0 & 0 & 1 & 2 & $0.100 \pm 0.200$ & 0.008 & $0.667 \pm 1.333$ \\
\hline $\begin{array}{l}\text { Gold nanoparticles } \\
1.25 \mathrm{mg} / \mathrm{ml}\end{array}$ & 1 & 0 & 1 & 0 & 0 & 0 & 1 & $0.050 \pm 0.100$ & 0.005 & $0.333 \pm 0.667$ \\
\hline
\end{tabular}

SD- Standard Deviation; *Significant criteria are fixed as $\mathrm{P} \leq 0.005$

\subsection{In vivo micronucleus assay.}

Micronucleus assay to find out the chromosomal damage of drugs. This study was carried out using gold nanoparticles $(150,300$, and $600 \mathrm{mg} / \mathrm{kg}$ body weight $)$ treated with mice. The ratio of polychromatic erythrocytes (PCE):normochromatic erythrocytes (NCE) and percentage micro-nucleated polychromatic erythrocytes (\% MNPCEs) results were observed calculated. For all the concentrations of gold nanoparticles, i.e., 150,300, and $600 \mathrm{mg} / \mathrm{kg}$ body weight studied, there was no significant dose-related increase in PCE:NCE ratio and micronuclei frequency in PCEs compared to the negative and positive control groups. Noticeably, an increase in \% MNPCE of Cyclophosphamide monohydrate (positive control treated group (G2 and G7) at 40 $\mathrm{mg} / \mathrm{kg}$ b.w was observed at $24 \mathrm{~h}$ and $48 \mathrm{~h}$ sampling, which verifies the completeness and accuracy of the experiment. Further, this assay also indicated that cyclophosphamide monohydrate at $40 \mathrm{mg} / \mathrm{kg}$ body weight induces micronuclei formation in mice erythroblasts due to damage in chromosomes or mitotic apparatus (Table. 4). George et al. [21] reported that chromosomal aberration and micronucleus assays were studied with chemically prepared citratestabilized gold nanoparticles ( $15 \mu \mathrm{g} / \mathrm{ml}-14 \mathrm{~nm}$ AuNP) non-statistically significant chromosomal DNA damage was observed. Downs et al. [22] reported that AuNPs within the particle size range from 2 to $200 \mathrm{~nm}$ failed to increase the circulating micronucleated reticulocytes (MNRETs) or RETs compared with positive control. Cyclophosphamide showed a remarkable increase in \% MN-RETs and a decrease in \% RETs in circulation. The study results confirmed that gold nanoparticles did not cause genotoxic effects. 
Table 4. Results of PCE:NCE ratio and \% MNPCE of female rats treated with gold nanoparticles.

\begin{tabular}{|c|c|c|c|c|}
\hline Group \& Group No. & $\begin{array}{c}\text { Dose } \\
\text { (mg/kg body weight) }\end{array}$ & $\begin{array}{c}\text { Sampling } \\
\text { time }\end{array}$ & $\begin{array}{l}\text { PCE:NCE } \\
\text { ratio }\end{array}$ & \% MNPCE \\
\hline $\begin{array}{l}\text { Negative Control- } 0.05 \% \text { Sodium Carboxy } \\
\text { Methyl Cellulose (G1) }\end{array}$ & 0 & \multirow{5}{*}{$24 \mathrm{~h}$} & $0.432 \pm 0.032$ & $0.065 \pm 0.024$ \\
\hline $\begin{array}{l}\text { Cyclophosphamide monohydrate (Positive } \\
\text { Control) (G2) }\end{array}$ & 40 & & $2.361 \pm 0.189$ & $1.615 \pm 0.067^{*}$ \\
\hline Gold nanoparticles (G3) & 150 & & $0.656 \pm 0.029$ & $0.075 \pm 0.035$ \\
\hline Gold nanoparticles (G4) & 300 & & $0.735 \pm 0.024$ & $0.090 \pm 0.032$ \\
\hline Gold nanoparticles (G5) & 600 & & $0.889 \pm 0.037$ & $0.085 \pm 0.034$ \\
\hline $\begin{array}{l}\text { Negative Control- } 0.05 \% \text { Sodium Carboxy } \\
\text { Methyl Cellulose (G6) }\end{array}$ & 0 & \multirow{5}{*}{$48 \mathrm{~h}$} & $0.455 \pm 0.014$ & $0.065 \pm 0.024$ \\
\hline $\begin{array}{l}\text { Cyclophosphamide monohydrate (Positive } \\
\text { Control) (G7) }\end{array}$ & 40 & & $2.486 \pm 0.122$ & $1.650 \pm 0.078^{*}$ \\
\hline Gold nanoparticles (G8) & 150 & & $0.669 \pm 0.024$ & $0.085 \pm 0.034$ \\
\hline Gold nanoparticles (G9) & 300 & & $0.797 \pm 0.038$ & $0.080 \pm 0.035$ \\
\hline Gold nanoparticles (G10) & 600 & & $0.915 \pm 0.030$ & $0.085 \pm 0.024$ \\
\hline
\end{tabular}

Note: PCE: NCE ratio and \% MNPCE expressed in Mean \& Standard Deviation, PCE- Polychromatic Erythrocyte, NCENormochromatic Erythrocyte and MNPCE-Micronucleated Polychromatic Erythrocyte, Values are expressed as Mean \pm SD, $(\mathrm{n}=3)$, * Significant at $\mathrm{P}<0.050$

\section{Conclusions}

The in vitro chromosomal aberration and in vivo micronucleus assay were studied to evaluate the genotoxic effects of gold nanoparticles. Significantly, there were no significant chromosomal aberrations quantified, most of which were chromatid breaks and chromosome exchanges. Both these assays showed that the genotoxicity response observed with gold nanoparticles was similar, and hence it can be concluded that gold nanoparticles were not genotoxic substances. Also, this study confirmed that gold nanoparticles were not found to be clastogenic. Therefore, the present study indicates that the gold nanoparticles do not induce the genotoxic and can be used in further applications.

\section{Funding}

This research received no external funding.

\section{Acknowledgments}

The authors thank the Centre for Toxicology and Developmental Research, Sri Ramachandra Institute of Higher Education and Research for in vitro and in vivo study.

\section{Conflicts of Interest}

The authors declare no conflict of interest.

\section{References}

1. Xin, Y.; Yin, M.; Zhao, L.; Meng, F.; Luo, L. Recent progress on nanoparticle-based drug delivery systems for cancer therapy. Cancer Biol Med. 2017, 14, 228-241, https://doi.org/10.20892/j.issn.2095-3941.2017.0052.

2. Patra, J.K.; Das, G.; Fraceto, L.F.; Campos, E.V.R.; Torres, M.P.; Torres, L.S.A.; Diaz-Torres, L.A.; Grillo, R.; Swamy, M.K.; Sharma, S.; Habtemariam, S.; Shin, H.S. Nano based drug delivery systems: recent developments and future prospects. J Nanobiotechnol.2018, 16, 71, https://doi.org/10.1186/s12951-018-0392-8.

3. Huo, Q.; Worden, J.G. Monofunctional gold nanoparticles: synthesis and applications. J Nanopart Res, 2007, 9, 1013-1025, https://doi.org/10.1007/s11051-006-9170-x.

4. Han, G.; Ghosh, P.; De, M.; Rotello, V.M. Drug and gene delivery using gold nanoparticles. Nanobiotech. 2007, 3, 40-45, https://doi.org/10.1007/s12030-007-0005-3.

5. Huang, J.; Li, Q.; Sun, D.; Lu, Y.; Su, Y.; Yang, X. Biosynthesis of silver and gold nanoparticles by novel sundried Cinnamomum camphora leaf. Nanotechnology 2007, 18, 105104, https://doi.org/10.1088/0957$4484 / 18 / 10 / 105104$. 
6. Rodriguez-Rocha, H.; Garcia-Garcia, A.; Panayiotidis, M.I.; Franco, R. DNA damage and autophagy. Mutat Res. 2011, 711, 158-166, https://doi.org/10.1016/j.mrfmmm.2011.03.007.

7. Mateuca, R.; Lombaert, N.; Aka, P. V.; Decordier, I.; Kirsch-Volders, M. Chromosomal changes: induction, detection methods and applicability in human biomonitoring. Biochimie 2006, 88, 1515-1531, https://doi.org/10.1016/j.biochi.2006.07.004.

8. Kirsch-Volders, M.; Vanhauwaert, A.; De Boeck, M.; Decordier, I. Importance of detecting numerical versus structural chromosome aberrations. Mutat Res. 2002, 504, 137-148, https://doi.org/10.1016/S00275107(02)00087-8.

9. Pfeiffer, P.; Goedecke, W.; Obe, G. Mechanisms of DNA double strand repair and their potential to induce chromosomal aberrations. Mutagenesis 2000, 15, 289-302, https://doi.org/10.1093/mutage/15.4.289.

10. Luzhna, L.; Kathiria, P.; Kovalchuk, O. Micronuclei in genotoxicity assessment: from genetics to epigenetics and beyond. Front Genet. 2013, 4, 131. https://doi.org/10.3389/fgene.2013.00131.

11. Terradas, M.; Martin, M.; Tusell, L.; Genesca, A. Genetic activities in micronuclei: is the DNA entrapped in micronuclei lost for the cell?. Mutat Res. 2010, 705, 60-67, https://doi.org/10.1016/j.mrrev.2010.03.004.

12. Deepak, A.K.; Darsha Kumar, D.M.; Chintamani Joshi,; Katti, K.V.; Kavita, K. Preparation and characterization of nano swarna bhasma. International Journal of Innovative Pharmaceutical Sciences and Research 2018, 6 , 68-72, https://doi.org/10.21276/IJIPSR.2018.06.07.720.

13. OECD (2016), Test No. 473: In Vitro Mammalian Chromosomal Aberration Test, OECD Guidelines for the Testing of Chemicals, Section 4, OECD Publishing, Paris, https://doi.org/10.1787/9789264264649-en.

14. OECD (2014), Test No. 474: Mammalian Erythrocyte Micronucleus Test, OECD Publishing, Paris, https://doi.org/10.1787/9789264224292-en.

15. Gong, T.; Olivo, M.; Dinish, U. S.; Goh, D.; Kong, K. V.; Yong, K.T. Engineering bioconjugated gold nanospheres and gold nanorods as label-free plasmon scattering probes for ultrasensitive multiplex dark-field imaging of cancer cells. J Biomed Nanotechnol 2013, 9, 985-91, https://doi.org/10.1166/jbn.2013.1603.

16. Gibson, J.D.; Bshnu, P.K.; Eugene, R.Z. Paclitaxel-functionalized gold nanoparticles. J Am Chem Soc. 2007, 129, 11653-11661, https://doi.org/10.1021/ja075181k.

17. Ashokkumar, T.; Jesu Arockiaraj, A.; Vijayaraghavan, K. Biosynthesis of gold nanoparticles using green roof species portulaca grandiflora and their cytotoxic effects against C6 glioma human cancer cells. Environmental Progress \& Sustainable Energy 2016, 35, 1732-1740, https://doi.org/10.1002/ep.12385.

18. Xia, Q.; Li, H.; Liu, Y.; Zhang, S.; Feng, Q.; Xiao, K. The Effect of particle size on the genotoxicity of gold nanoparticles. J Biomed Mater Res A 2017, 105, 710-719, https://doi.org/10.1002/jbm.a.35944.

19. Das, P.; Chetia, B.; Prasanth, R.; Madhavan, J.; Singaravelu, G.; Benelli, G.; Murugan, K. Green nanosynthesis and functionalization of gold nanoparticles as PTP 1B inhibitors. J Clust Sci 2017, 28, 2269-2277, https://doi.org/10.1007/s10876-017-1224-y.

20. Schrepler, P.M.; David, L.; Olenic, L.; Potara, M.; Fischer-Fodor, E.; Virag, P. qA. Gold nanoparticles synthesized with a polyphenols-rich extract from cornelian cherry (Cornus mas) fruits: Effects on human skin cells. J Nanomater 2016, 2016, Article ID 6986370, https://doi.org/10.1155/2016/6986370.

21. George, J.M.; Magogotya, M.; Vetten, M.A.; Buys, A.V.; Gulumian, M. An investigation of the genotoxicity and interference of gold nanoparticles in commonly used in vitro mutagenicity and genotoxicity assays. Toxicological sciences 2017, 156, 149-166, https://doi.org/10.1093/toxsci/kfw247.

22. Downs, T. R.; Crosby, M. E.; Hu, T.; Kumar, S.; Sullivan, A.; Sarlo, K. Silica nanoparticles administered at the maximum tolerated dose induce genotoxic effects through an inflammatory reaction while gold nanoparticles do not. Mutat Res. 2012, 745, 38-50, https://doi.org/10.1016/j.mrgentox.2012.03.012. 